\title{
In vitro resynthesis of lichenization reveals the genetic background of symbiosis- specific fungal-algal interaction in Usnea hakonensis
}

\author{
Mieko Kono ${ }^{1,2^{*}}$ (D, Yoshiaki Kon ${ }^{3}$, Yoshihito Ohmura ${ }^{4}$, Yoko Satta ${ }^{1}$ and Yohey Terai ${ }^{1}$
}

\begin{abstract}
Background: Symbiosis is central to ecosystems and has been an important driving force of the diversity of life. Close and long-term interactions are known to develop cooperative molecular mechanisms between the symbiotic partners and have often given them new functions as symbiotic entities. In lichen symbiosis, mutualistic relationships between lichen-forming fungi and algae and/or cyanobacteria produce unique features that make lichens adaptive to a wide range of environments. Although the morphological, physiological, and ecological uniqueness of lichens has been described for more than a century, the genetic mechanisms underlying this symbiosis are still poorly known.
\end{abstract}

Results: This study investigated the fungal-algal interaction specific to the lichen symbiosis using Usnea hakonensis as a model system. The whole genome of $U$. hakonensis, the fungal partner, was sequenced by using a culture isolated from a natural lichen thallus. Isolated cultures of the fungal and the algal partners were co-cultured in vitro for 3 months, and thalli were successfully resynthesized as visible protrusions. Transcriptomes of resynthesized and natural thalli (symbiotic states) were compared to that of isolated cultures (non-symbiotic state). Sets of fungal and algal genes up-regulated in both symbiotic states were identified as symbiosis-related genes.

Conclusion: From predicted functions of these genes, we identified genetic association with two key features fundamental to the symbiotic lifestyle in lichens. The first is establishment of a fungal symbiotic interface: (a) modification of cell walls at fungal-algal contact sites; and (b) production of a hydrophobic layer that ensheaths fungal and algal cells; : The second is symbiosis-specific nutrient flow: (a) the algal supply of photosynthetic product to the fungus; and (b) the fungal supply of phosphorous and nitrogen compounds to the alga. Since both features are widespread among lichens, our result may indicate important facets of the genetic basis of the lichen symbiosis.

Keywords: Lichen symbiosis, Resynthesis, Mycobiont-photobiont interaction, Genetic background

\footnotetext{
* Correspondence: mieko.kono10001@gmail.com

'SOKENDAI (The Graduate University for Advanced Studies), Department of

Evolutionary Studies of Biosystems, Shonan Village, Hayama, Kanagawa

240-0193, Japan

${ }^{2}$ Department of Botany, Swedish Museum of Natural History, P.O. Box 50007,

SE-104 05 Stockholm, Sweden

Full list of author information is available at the end of the article
}

C C The Author(s). 2020 Open Access This article is licensed under a Creative Commons Attribution 4.0 International License, which permits use, sharing, adaptation, distribution and reproduction in any medium or format, as long as you give appropriate credit to the original author(s) and the source, provide a link to the Creative Commons licence, and indicate if changes were made. The images or other third party material in this article are included in the article's Creative Commons licence, unless indicated otherwise in a credit line to the material. If material is not included in the article's Creative Commons licence and your intended use is not permitted by statutory regulation or exceeds the permitted use, you will need to obtain permission directly from the copyright holder. To view a copy of this licence, visit http://creativecommons.org/licenses/by/4.0/. The Creative Commons Public Domain Dedication waiver (http://creativecommons.org/publicdomain/zero/1.0/) applies to the data made available in this article, unless otherwise stated in a credit line to the data. 


\section{Background}

Lichens are symbiotic associations that are adapted to a wide range of environments. They are often found in extreme environments where other organisms have difficulty surviving. In lichens, symbiotic partners are known to develop a highly integrated association that requires appropriate recognition and communication to construct and maintain a functional symbiotic entity. From the classical point of view, lichens are considered to consist of a fungal species (mycobiont) forming the basis of a symbiosis-specific structure referred to as a thallus, and a photosynthetic species (photobiont) that provides the entire thallus with carbon nutrition [1-3]. Although recent findings have brought up controversial issues of the members involved in lichen symbioses [4-6], several experiments have shown that in vitro co-culturing of the mycobiont and the photobiont can initiate development of symbiotic phenotypes to a limited extent [7-10]. Field and culture observations have described development of lichen symbiosis (lichenization) in sequential stages: 1) pre-contact, 2) contact, 3) envelopment of algal cells, 4) incorporation of both symbionts into a common matrix (pre-thallus formation), and 5) thallus differentiation [8]. So far primarily early stages of lichenization have been investigated and genes of mycobionts and photobionts have been reported as those likely to function in lichen symbioses [11-13]. An in vitro resynthesis model system is more suitable than natural material to identify the genes involved in the basis of symbiosis because it can control for absence of other factors affecting the symbiosis. However, later stages of lichenization are rarely achievable in vitro and therefore transcriptomic studies have been limited to the early stages. Recognition of compatibility between the mycobiont and the photobiont is known to start in early stages [9, 14, 15] and only compatible combinations are known to form a differentiated thallus [7, 8, 16-18]. For that reason, later stages, especially thallus differentiation, are more likely to reflect unique characters of lichens, and investigation into genetic mechanisms that control the development of those stages is essential to understanding the fundamental nature of lichen symbiosis.

Here, we use Usnea hakonensis Asahina as a new resynthesis model for studying the genetics of the lichen symbiosis. This species is characterized by having a sorediate fruticose thallus with a cortex, medulla and a cartilaginous central axis, with the presence of usnic acid in the cortex and unidentified substances (US1, US2) in the medulla [19]. The resynthesis model of $U$. hakonensis is distinct from other models [10-12] in routinely establishing thallus-like fibrils when the mycobiont $U$. hakonensis and the photobiont Trebouxia sp. are cocultured in vitro (Fig. 1). Although resynthesized $U$. hakonensis cannot develop into a mature thallus, Kon et al. [20] observed that the inner structure of fibrils differentiated into a cortex, medulla and axis, all of which resemble that of a natural thallus. To the best of our knowledge, resynthesized lichens with differentiated thallus structures have not been investigated using the tools of molecular genetics. By using this $U$. hakonensis model, we aimed to identify a core set of genes that function in later stages of development, vital for the mycobiont and the photobiont to stabilize the symbiotic interaction. For this purpose, we examined the transcriptomes of $U$. hakonensis when: 1$)$ the mycobiont $U$. hakonensis, and the photobiont Trebouxia sp. isolates are cultured independently (non-symbiotic state); 2) the symbiotic phenotype is resynthesized in vitro (resynthesized symbiotic state); and 3 ) $U$. hakonensis is in

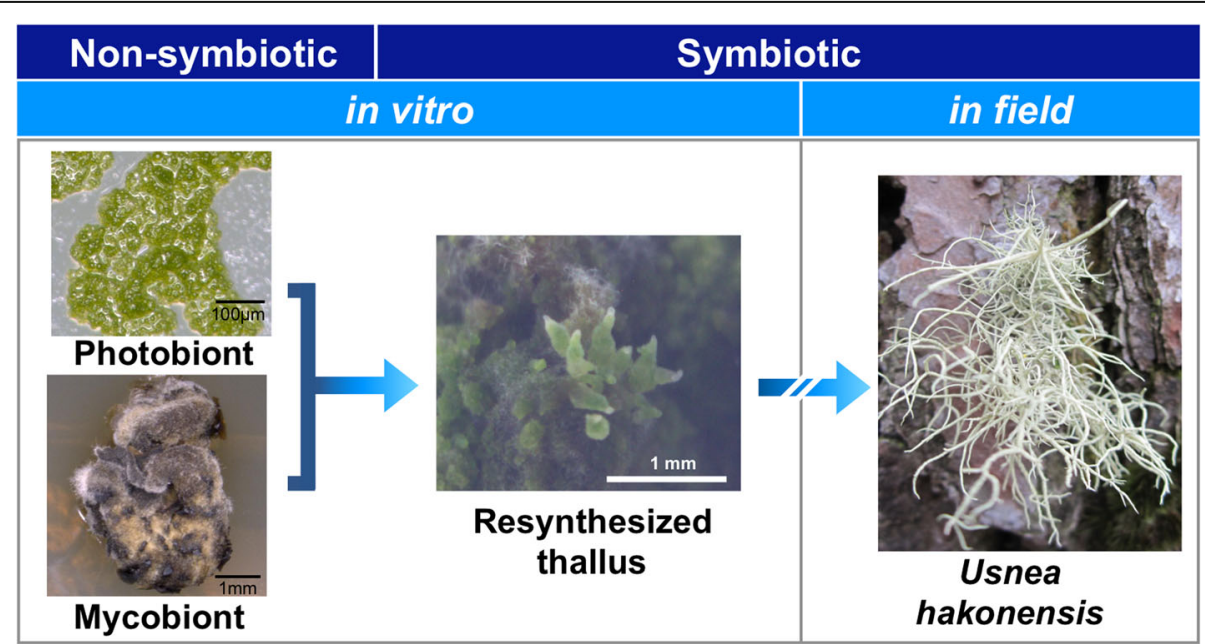

Fig. 1 Resynthesis of lichen Usnea hakonensis. Co-culturing of the mycobiont (U. hakonensis: lower left) and the photobiont (Trebouxia sp.: upper left) isolates initiates the development of a symbiotic thalloid structure (centre), which is not a true thallus but presents morphologically and biochemically similar features as a natural thallus (right). The images were taken by the authors 
the field (natural symbiotic state). The comparative transcriptomic analysis between the non-symbiotic state and the two symbiotic states can identify sets of fungal and algal genes that show up- or down-regulation in the symbiotic states. Predicted functions of the genes can indicate their relevance to symbiosis-specific features of lichens as presented in previous studies on early stages of lichenization $[12,13]$.

\section{Results}

\section{De novo assembly and annotation of the genomes}

The genome of the mycobiont, Usnea hakonesis, was de novo assembled from $227 \mathrm{M}$ Illumina Hiseq paired-end reads $(125 \mathrm{bp})$. The genome size predicted from the sum of 2454 scaffolds is $42.0 \mathrm{Mb}$. The average coverage and N50 value are 589X and $163 \mathrm{~kb}$ respectively. Sequencing and assembly of the algal genome $(69 \mathrm{Mb})$ has been reported elsewhere [21]. Table 1 shows the basic features of the genomes. The assembled fungal and algal genomes contained 97.0 and $90.5 \%$ of the core eukaryotic genes, respectively. Approximately $99 \%$ of the reads used in the assembly was mapped back to 879 fungal and 677 algal scaffolds larger than $2 \mathrm{~kb}$ that contain all identified core eukaryotic genes. The genic regions in these scaffolds were determined by using $436 \mathrm{M}$ fungal and $247 \mathrm{M}$ algal RNA-seq reads (The number of reads yielded from each sample type is summarized in Additional file 1: Table S1), respectively. In total, 21,105 and 21,190 genic regions (including the sequences of non-coding RNA) were annotated to the fungal and algal scaffolds $(>2 \mathrm{~kb})$, respectively.

\section{Identification of symbiosis-related genes and functional prediction}

The expression of the annotated genes was compared between each symbiotic state (resynthesized and natural

Table 1 Basic features of the genomes

\begin{tabular}{lll}
\hline Genome & Usnea hakonensis & $\begin{array}{l}\text { Trebouxia sp. } \\
\text { TZW2008 }\end{array}$ \\
\hline Genome size (Mb) & 42.0 & 69.9 \\
Number of scaffolds & 2454 & 1973 \\
Coverage & $589 x$ & $526 x$ \\
N50 (kb) & 163 & 221 \\
GC content (\%) & 45.5 & 49.7 \\
Number of scaffolds (> 2 kb) & 879 & 677 \\
Number of genes & 21,105 & 21,190 \\
Number of mRNA & 26,898 & 29,192 \\
Number of genes overlapping & 1626 & 907 \\
Average length of gene & 1071 & 2261 \\
Average \# of exons per mRNA & 2.1 & 4.4 \\
\hline
\end{tabular}

thalli) and the non-symbiotic state (isolated cultures). RNA was extracted from $U$. hakonensis thalli collected in the field, thallus-like fibrils resynthesized on top of mycobiont-photobiont mixed cultures after 3 months of co-culturing, and fugal and algal colonies independently cultured for 1 month (see Method "Sample preparation for RNA sequencing" section for the choice of the culture conditions). In total, $193 \mathrm{M}, 169 \mathrm{M}$, and $74 \mathrm{M}$ fungal reads and $97 \mathrm{M}, 66 \mathrm{M}$, and $84 \mathrm{M}$ algal reads from the resynthesized, natural, symbiotic states and the nonsymbiotic state, respectively, were used to compare the expression of the annotated genes (Additional file 1: Table S1). Differentially expressed genes (DEGs) with corrected $p$-value $<0.05$ (Bonferroni correction) were considered significant. In the resynthesized and natural symbiotic states, 1788 and 4033 fungal genes, and 728 and 3229 algal genes were identified as significant DEGs (Table 2). Among the significant DEGs, 305 fungal and 203 algal genes were consistently up-regulated in the resynthesized and natural symbiotic states relative to the non-symbiotic state, and 672 fungal and 202 algal genes were consistently down-regulated. The fungal consistent up- and down-regulated genes were both significantly over-represented in 'oxidation-reduction process' ( $p$-value $=$ $4.60 \mathrm{e}-04$ and $p$-value $=3.40 \mathrm{e}-06)$, a biological process category of Gene Ontology (GO) terms (Additional file 1: Table S2 and S3). The algal consistent up- and downregulated genes were over-represented in one (translation $p$-value $=1.40 \mathrm{e}-16$ ) and two ('transmembrane transport' $p$-value $=2.70 \mathrm{e}-04$, 'protein folding' $p$-value $=7.90 \mathrm{e}-04)$ biological process categories, respectively (Additional file 1 : Table S4 and S5).

Among the significant DEGs, we specifically focused on the genes consistently up-regulated in both symbiotic states as 'symbiosis-related genes' (see Discussion). The symbiosis-related genes were subjected to BLASTX searches to obtain further functional information. Of the 305 fungal and 203 algal symbiosis-related genes, 153 $(50.2 \%)$ and 79 (38.9\%) had similar protein sequences in the database, respectively ( $e$-value $<1 \mathrm{e}-40)$. Among the genes that had similar protein sequences in the database, 58 fungal genes and 52 algal genes corresponded to proteins with predicted functions.

Table 2 The number of significant up-/down regulated genes identified in each comparison

\begin{tabular}{llllll}
\hline & \multicolumn{2}{l}{$\begin{array}{l}\text { Resynthesized vs } \\
\text { non-symbiotic }\end{array}$} & & \multicolumn{2}{l}{$\begin{array}{l}\text { Natural vs } \\
\text { non-symbiotic }\end{array}$} \\
\cline { 2 - 3 } & Fungal & Algal & & Fungal & Algal \\
\hline Up-regulated & 675 & 393 & & 2261 & 1776 \\
Down-regulated & 1113 & 335 & & 1772 & 1453 \\
Total DEGs & 1788 & 728 & & 4033 & 3229 \\
\hline
\end{tabular}




\section{Categorization of the symbiosis-related genes}

The fungal and algal symbiosis-related genes were manually classified into categories based on the biological process categories of $\mathrm{GO}$ according to their functions predicted from BLASTX and literature searches. As a result, 58 fungal and 52 algal genes were classified into 15 and 13 functional categories, respectively (Table 3 ). The largest number of symbiosis-related genes was assigned to 'transport' in the mycobiont and to 'transcription/translation' in the photobiont.

\section{Genes which may be involved in establishment of the symbiotic interface}

Several protein functions predicted from the symbioticrelated genes may be involved in the formation of a symbiotic interface, where the fungal hyphae and algal cells are attached (Table 4). The modification of fungal and algal cell walls at fungal-algal contact sites is suggested by the following fungal symbiosis-related genes. Two inferred proteins are similar to glycoside hydrolases in family 12 (Uhk_019559) and family 2 (Uhk_007999). Enzymes belonging to these families are known to degrade cellulose and hemicellulose, the main carbohydrate components of plant and green algae cell walls [22]. Two

Table 3 Categories of the symbiosis-related genes according to the functional information obtained from the BLASTX and literature searches

\begin{tabular}{lll}
\hline Category name & Fungal genes & Algal genes \\
\hline Amino acid synthesis & 1 & 3 \\
Carbohydrate metabolism & 2 & 1 \\
Cell wall organization & 5 & 0 \\
Cellular respiration & 3 & 0 \\
Cytochrome P450 & 5 & 0 \\
Development & 3 & 0 \\
Lipid metabolism & 7 & 2 \\
Methylation & 0 & 1 \\
Nitrogen metabolism & 0 & 2 \\
Phosphate metabolism & 0 & 1 \\
Photosynthesis & 0 & 4 \\
Proteolysis & 5 & 1 \\
Redox & 2 & 0 \\
Secondary metabolism & 1 & 0 \\
Signal transduction & 1 & 1 \\
Stress response & 3 & 2 \\
Transcription/translation & 3 & 25 \\
Transport & 11 & 5 \\
Xenobiotic metabolism & 3 & 1 \\
Uncategorized & 3 & 3 \\
Total & 58 & 52 \\
\hline
\end{tabular}

genes products show similarity to the enzymes involved in degradation and biogenesis of the fungal cell wall. Uhk 005214 showed significant similarities to beta-1,3-glucanases, enzymes that break down 1,3-beta glucan, the central component of the inner cell wall of fungi [2325]. Uhk_002614 showed similarities to enzymes in glycosyltransferase family 2 . This family includes enzymes involved in the biosynthesis of polysaccharides.

Hydrophobins (Uhk_016581) are low molecular mass hydrophobic proteins considered to be the main component of the hydrophobic layer that seals the fungal and algal cell wall surface at contact sites [2, 26]. Polyketide synthases (Uhk_016999) catalyse the synthesis of polyketides which have been reported to be deposited within and on the surface of the hydrophobic layer [2, 27]. Lipids and fatty acids have also been detected as components of this layer [28]. Sphinganine hydroxylase (Uhk_003277) and phosphatidylserine decarboxylase (Uhk_017380 and Uhk_017885) are involved in sphingolipid and phospholipid biosynthesis, respectively [29, 30]. Lipases encoded by Lip3 (Uhk_003579) and Lip2 (Uhk_013145), may break down triacylglycerols and produce fatty acids [31].

\section{Genes which may be involved in nutrient flow within thalli} Symbiosis-specific metabolism and transport of carbohydrate, phosphate, and nitrogen between the mycobiont and the photobiont is implicated from functions of the following symbiosis-related genes.

\section{Carbohydrate}

Four algal symbiosis-related genes were predicted to have functions related to photosynthesis (Table 5). Ttzw_014612 is similar to the D1 reaction centre protein in photosystem II [32]. Ttzw_000076 showed similarities to carbonic anhydrases which catalyse the reversible hydration of carbon dioxide, known to support photosynthesis by means of $\mathrm{CO}_{2}$ transport and/or involvement in carbon concentration mechanisms [33, 34]. Symbiosisspecific carbon assimilation is implicated by two symbiosisrelated genes, Ttzw_020492 and Ttzw_014778. The two may be involved in the synthesis of [4Fe-4S] chloroplastic protein ferredoxin:thioredoxin reductase (FTR), a key protein in the light-dependent regulatory system (ferredoxin/ thioredoxin system) $[35,36]$.

A high proportion of carbon fixed by photobionts is transported to mycobionts as their main carbon source [37]. Previous studies showed that the photosynthetic product released by Trebouxia photobionts and transferred to mycobionts is ribitol, the five carbon polyol [38-40]. Three fungal symbiosis-related genes (Uhk_000003, Uhk 000004, and Uhk_011461) showed similarities to fungal polyol transporters as well as fungal sugar transporters STL1 (Table 5). Uhk_000003 and Uhk_000004 showed significant similarities to a fungal polyol transporter AmLAT2 
Table 4 Fungal symbiosis-related genes predicted to be related to establishment of the symbiotic interface

\begin{tabular}{|c|c|c|c|c|c|}
\hline \multirow[t]{2}{*}{ Symbiont } & \multirow[t]{2}{*}{ Gene ID } & \multicolumn{2}{|c|}{ Corrected $p$-value } & \multirow[t]{2}{*}{ Predicted function } & \multirow[t]{2}{*}{ Category } \\
\hline & & Resynthesized & natural & & \\
\hline Fungus & Uhk_002614 & $5.22 \mathrm{e}-06$ & $2.43 e-126$ & glycosyltransferase family 2 & cell wall organization \\
\hline Fungus & Uhk_005214 & $6.46 \mathrm{e}-10$ & $6.40 \mathrm{e}-31$ & 1,3-beta glucanase & cell wall organization \\
\hline Fungus & Uhk_007999 & $2.34 \mathrm{e}-45$ & $4.36 \mathrm{e}-07$ & glycoside hydrolase family 2 protein & cell wall organization \\
\hline Fungus & Uhk_019559 & $2.70 e-79$ & $3.34 \mathrm{e}-25$ & glycoside hydrolase family 12 protein & cell wall organization \\
\hline Fungus & Uhk_021074 & $2.10 e-27$ & $1.42 \mathrm{e}-71$ & carbohydrate-binding module 32 & cell wall organization \\
\hline Fungus & Uhk_016581 & $1.60 \mathrm{e}-102$ & $2.32 \mathrm{e}-182$ & hydrophobin & - \\
\hline Fungus & Uhk_003277 & $3.30 e-69$ & $1.32 \mathrm{e}-24$ & similar to sphinganine hydroxylase Sur2 & lipid metabolism \\
\hline Fungus & Uhk_017380 & $1.76 \mathrm{e}-15$ & $2.71 e-39$ & phosphatidylserine decarboxylase & lipid metabolism \\
\hline Fungus & Uhk_017885 & $2.98 \mathrm{e}-11$ & $1.45 e-05$ & $\begin{array}{l}\text { phosphatidylserine decarboxylase } \\
\text { proenzyme } 3\end{array}$ & lipid metabolism \\
\hline Fungus & Uhk_003579 & $1.59 \mathrm{e}-11$ & $1.41 \mathrm{e}-15$ & Lip3 precursor & lipid metabolism \\
\hline Fungus & Uhk_013145 & $2.20 \mathrm{e}-05$ & $3.85 e-42$ & lipase 2 & lipid metabolism \\
\hline Fungus & Uhk_008459 & $5.40 \mathrm{e}-06$ & $8.20 \mathrm{e}-16$ & carboxylesterase type B & lipid metabolism \\
\hline Fungus & Uhk_016999 & $4.54 \mathrm{e}-05$ & $1.79 e-20$ & reducing polyketide synthase & secondary metabolism \\
\hline
\end{tabular}

(e-value $\leq 2 \mathrm{e}-52$, \% a.a. identity $\geq 52.8 \%$ ) which is reported to transport ribitol [41]. On the other hand, Uhk_011461 showed significant similarities to a glycerol transporter DhStl1 (e-value: 5e-47, \% a.a. identity: 47.8) [42]. The expression of the glycerol transporter is possibly correlated with a glycerol dehydrogenase (Uhk_011759) which was also identified as a symbiosis-related gene (see Discussion).

\section{Phosphate}

Fungal symbiosis-related genes predicted to code for acid phosphatase (Uhk_006220) and MFS phosphate transporter (Uhk_019687) may be involved in the metabolism and transport of inorganic phosphate (Pi) from the mycobiont to the photobiont (Table 6). The putative acid phosphatase also shows significant similarities to the $5^{\prime} / 3^{\prime}$-nucleosidase SurE which is reported to hydrolyse polyphosphate [43]. On the other hand, no algal phosphate transporter gene was identified as symbiosisrelated. One algal $\mathrm{H}+/ \mathrm{Pi}$ symporter (Ttzw_012184) was significantly up-regulated in the natural thalli but not in the resynthesized thalli. An algal symbiosis-related gene encoding transmembrane ATPase (Ttzw_021111) may be related to proton electrochemical gradient production that energizes the uptake of phosphate by phosphate transporters (see Discussion).

\section{Nitrogen}

The symbiosis-specific modification of nitrogen metabolism by $\mathrm{P}_{\mathrm{II}}$ signaling proteins is indicated in the photobiont (Table 7). The conformational change of $\mathrm{P}_{\mathrm{II}}$ proteins alters their binding affinities for the target proteins thereby controlling activities of the targets $[44,45]$.

Table 5 Fungal and algal symbiosis-related genes predicted to be related to carbohydrate flow between the symbionts

\begin{tabular}{|c|c|c|c|c|c|}
\hline \multirow[t]{2}{*}{ Symbiont } & \multirow[t]{2}{*}{ Gene ID } & \multicolumn{2}{|c|}{ Corrected $p$-value } & \multirow[t]{2}{*}{ Predicted function } & \multirow[t]{2}{*}{ Category } \\
\hline & & Resynthesized & Natural & & \\
\hline Fungus & Uhk_000003 & $1.02 e-148$ & $3.38 \mathrm{e}-54$ & sugar transporter stl1 & transport \\
\hline Fungus & Uhk_000004 & $9.98 e-186$ & $4.11 e-82$ & sugar transporter stl1 & transport \\
\hline Fungus & Uhk_011461 & $1.55 \mathrm{e}-05$ & $6.14 \mathrm{e}-23$ & sugar transporter stl1 & transport \\
\hline Fungus & Uhk_011759 & $1.60 \mathrm{e}-09$ & $5.44 \mathrm{e}-81$ & glycerol dehydrogenase Gcy1 & carbohydrate metabolism \\
\hline Fungus & Uhk_015443 & $8.40 \mathrm{e}-04$ & $1.05 e-16$ & 6-phosphogluconolactonase & carbohydrate metabolism \\
\hline Alga & Ttzw_019219 & $1.60 \mathrm{e}-05$ & $1.52 \mathrm{e}-17$ & sorbitol dehydrogenase & carbohydrate metabolism \\
\hline Alga & Ttzw_020492 & $8.33 e-07$ & $8.31 e-29$ & FeS cluster assembly accessory/regulatory protein & photosynthesis \\
\hline Alga & Ttzw_014778 & $2.82 \mathrm{e}-05$ & $1.62 \mathrm{e}-20$ & chloroplast ferredoxin-thioredoxin reductase & photosynthesis \\
\hline Alga & Ttzw_014612 & $1.73 e-09$ & $1.80 e^{-116}$ & D1 reaction centre protein of photosystem II & photosynthesis \\
\hline Alga & Ttzw_000076 & $3.22 \mathrm{e}-02$ & $4.87 e-16$ & carbonic anhydrase & photosynthesis \\
\hline
\end{tabular}


Table 6 Fungal and algal DEGs predicted to be related to phosphate flow between the symbionts

\begin{tabular}{|c|c|c|c|c|c|}
\hline \multirow[t]{2}{*}{ Symbiont } & \multirow[t]{2}{*}{ Gene ID } & \multicolumn{2}{|c|}{ Corrected $p$-value } & \multirow[t]{2}{*}{ Predicted function } & \multirow[t]{2}{*}{ Category } \\
\hline & & Resynthesized & Natural & & \\
\hline \multicolumn{6}{|c|}{ Symbiosis related genes (consistently up-regulated) } \\
\hline Fungus & Uhk_006220 & $1.75 e-02$ & $1.43 e-19$ & acid phosphatase precursor / 5'/3'-nucleotidase & phosphate metabolism \\
\hline Fungus & Uhk_019687 & $3.70 e-04$ & $2.44 \mathrm{e}-64$ & MFS phosphate transporter & transport \\
\hline Alga & Ttzw_008450 & $3.69 \mathrm{e}-04$ & $1.56 \mathrm{e}-90$ & soluble inorganic pyrophosphatase 2 & phosphate metabolism \\
\hline Alga & Ttzw_021111 & $1.31 \mathrm{e}-12$ & $5.76 e-13$ & transmembrane ATPase & transport \\
\hline \multicolumn{6}{|c|}{ Up-regulated DEGS in natural symbiotic state } \\
\hline Alga & Ttzw_012184 & 1.00 & $2.01 \mathrm{e}-18$ & proton/phosphate symporter & transport \\
\hline
\end{tabular}

In the chloroplast of plants and algae, $\mathrm{P}_{\mathrm{II}}$ proteins are known to function in signal transduction of cellular nitrogen metabolism responding to cellular glutamine level $[44,45]$. The algal symbiosis-related Ttzw_019382 may change the conformation of $\mathrm{P}_{\mathrm{II}}$ proteins via uridylylation of amino acid residues depending on the cellular glutamine level. Another symbiosis-related protein, Ttzw 009103, could be relevant to the cellular glutamine level by catalysing the removal of the ammonia group from glutamine. Fungal nitrate, nitrite, amino acid transporter, and algal amino acid transporter genes were up-regulated in each symbiotic state but were not consistent between the two symbiotic states.

\section{Discussion}

Symbioses have driven a number of evolutionary innovations in the history of life. Genomic investigations into mutualistic symbioses between insects and bacteria, corals and dinoflagellates, have revealed that long and intimate associations can result in genomic modification of both symbionts, reflecting their symbiotic relationships [46-50]. Their heterotrophic nature led fungi to evolve mutualistic symbioses with other organisms that provide them with various nutrients, namely carbon. The most well-studied examples are mycorrhizal fungi that form mutualistic associations with more than $90 \%$ of extant plant species [51]. Numerous molecular studies have characterized fungal and plant genes involved in the steps leading to functional symbiosis [51]. On the other hand, genetic mechanisms of the lichen symbiosis, distributed among ca. $20 \%$ of all fungal species and considered as one of the most successful mutualistic symbioses, remain largely unknown. Unlike other mutualistic symbioses between fungi and photoautotrophs, lichens are unique in the development of a symbiotic structure that often includes complete envelopment of algal/ cyanobacterial cells by fungal hyphae [8]. Within this symbiotic structure the fungus (mycobiont) optimizes illumination, gas exchange, water and nutrient supply to create a favourable and protective environment for the photosynthetic partner (photobiont) which produces photosynthetic products that nourish not only itself but the entire lichen.

Here, from the results of our comparative transcriptomic analysis between the non-symbiotic and symbiotic states of the Usnea hakonenesis system, we identify genes specifically expressed in the later lichenization stage, thallus differentiation, and hypothesize the genetic mechanisms involved in the development of a functional symbiotic structure. The advantage of the laboratory experiment is that it can control factors affecting the symbiotic interaction. However, resynthesized thalli of $U$. hakonensis cannot develop a symbiotic phenotype identical to that of the natural [20]. To counter these shortcomings we focused on the significant differentially expressed genes (DEGs) that are consistent between the two symbiotic states. The imposition of consistency decreased the number of available DEGs but successfully filtered genes more relevant to the symbiosis.

The significant over-representation of the GO term 'transmembrane transport' among the algal consistently down-regulated genes in the symbiotic states may indicate active nutrient transports in the non-symbiotic culture where algal cells have direct contact with the medium. On the other hand, the GO term 'oxidation-reduction process' was over-represented both among the up- and downregulated fungal genes in the symbiotic states. Although the assigned genes predicted to be involved in the oxidationreduction process of various metabolic activities are similar, genes involved in defence against oxidative stress, such as alternative oxidase, thioredoxin, and thioredoxin reductase, were only identified among the down-regulated genes. In lichens, both enzymatic and non-enzymatic antioxidants are suggested to be involved in protection from oxidative stress [52]. The down-regulation of these genes in the symbiotic states possibly indicates a shift in fungal preference for antioxidants upon symbiosis. The $U$. hakonensis system might also be well suited for investigation into stress physiology of lichens. 
Table 7 Fungal and algal DEGs predicted to be related to nitrogen flow between the symbionts

\begin{tabular}{|c|c|c|c|c|c|}
\hline \multirow[t]{2}{*}{ Symbiont } & \multirow[t]{2}{*}{ Gene ID } & \multicolumn{2}{|c|}{ Corrected $p$-value } & \multirow[t]{2}{*}{ Predicted function } & \multirow[t]{2}{*}{ Category } \\
\hline & & Resynthesized & Natural & & \\
\hline \multicolumn{6}{|c|}{ Symbiosis related genes (consistently up-regulated) } \\
\hline Alga & Ttzw_019382 & $2.16 \mathrm{e}-08$ & $1.91 e-31$ & [Protein-PII] uridylyltransferase & nitrogen metabolism \\
\hline Alga & Ttzw_009103 & $1.72 \mathrm{e}-09$ & $7.46 \mathrm{e}-46$ & class I glutamine amidotransferase & nitrogen metabolism \\
\hline \multicolumn{6}{|c|}{ Up-regulated DEGs in resynthesized symbiotic state } \\
\hline Fungus & Uhk_003065 & $2.66 \mathrm{e}-71$ & 1.00 & glutaminase GtaA & amino acid synthesis \\
\hline Fungus & Uhk_005376 & $3.05 e-03$ & 1.00 & pyrroline-5-carboxylate reductase & amino acid synthesis \\
\hline Fungus & Uhk_002174 & $1.99 \mathrm{e}-03$ & 1.00 & amino acid transporter & transport \\
\hline Fungus & Uhk_018308 & $1.43 e-09$ & 1.00 & amino acid transporter & transport \\
\hline Fungus & Uhk_014550 & $7.35 e-09$ & 1.00 & nitrate transporter & transport \\
\hline Alga & Ttzw_015573 & $9.05 e-14$ & 1.00 & amino acid transmembrane transporter & transport \\
\hline Alga & Ttzw_000766 & $4.30 \mathrm{e}-10$ & 1.00 & proline transporter 2 & transport \\
\hline Alga & Ttzw_001223 & $3.31 e-23$ & 1.00 & amidase family protein & nitrogen metabolism \\
\hline Alga & Ttzw_003286 & $6.94 \mathrm{e}-13$ & 1.00 & amidase signature enzyme & nitrogen metabolism \\
\hline Alga & Ttzw_010289 & $2.46 \mathrm{e}-23$ & 1.00 & amidase signature enzyme & nitrogen metabolism \\
\hline Alga & Ttzw_017923 & $1.05 e-14$ & 1.00 & amidase signature enzyme & nitrogen metabolism \\
\hline Alga & Ttzw_019703 & $3.01 e-12$ & 1.00 & amidase signature enzyme & nitrogen metabolism \\
\hline Alga & Ttzw_006733 & $1.28 \mathrm{e}-02$ & 4.46e-01 & aminomethyltransferase & nitrogen metabolism \\
\hline Alga & Ttzw_012286 & $2.59 \mathrm{e}-26$ & $2.77 e-15$ & L-amino acid oxidase & nitrogen metabolism \\
\hline Alga & Ttzw_020564 & $6.83 e-10$ & $1.79 \mathrm{e}-29$ & urate oxidase II & nitrogen metabolism \\
\hline \multicolumn{6}{|c|}{ Up-regulated DEGs in natural symbiotic state } \\
\hline Fungus & Uhk_002719 & 1.00 & $3.94 \mathrm{e}-05$ & amino acid permease & transport \\
\hline Fungus & Uhk_003463 & 1.00 & $1.17 \mathrm{e}-04$ & amino acid transporter & transport \\
\hline Fungus & Uhk_001198 & 1.00 & $1.47 e-68$ & formate/nitrite transporter & transport \\
\hline Fungus & Uhk_003877 & 1.00 & $3.26 \mathrm{e}-101$ & type 1 glutamine amidotransferase & nitrogen metabolism \\
\hline Fungus & Uhk_019576 & 1.00 & $1.01 e-02$ & amidase & nitrogen metabolism \\
\hline Fungus & Uhk_019577 & 1.00 & $2.91 e-16$ & amidase & nitrogen metabolism \\
\hline Fungus & Uhk_016086 & $6.37 e-03$ & $4.32 \mathrm{e}-16$ & nitrogen metabolic regulation protein & nitrogen metabolism \\
\hline Fungus & Uhk_011793 & 1.00 & $1.60 \mathrm{e}-04$ & nitrogen assimilation transcription factor nira & nitrogen metabolism \\
\hline Fungus & Uhk_006314 & 1.00 & $3.85 e-04$ & acetylglutamate synthase & amino acid synthesis \\
\hline Fungus & Uhk_011793 & 1.00 & $1.60 \mathrm{e}-04$ & nitrogen assimilation transcription factor nira & nitrogen metabolism \\
\hline Alga & Ttzw_008144 & 1.00 & $1.34 \mathrm{e}-06$ & asparaginase/glutaminase & amino acid synthesis \\
\hline Alga & Ttzw_009365 & 1.00 & $2.74 \mathrm{e}-06$ & glutamine-hydrolyzing asparagine synthase & amino acid synthesis \\
\hline Alga & Ttzw_005836 & 1.00 & $6.98 \mathrm{e}-16$ & pyrroline-5-carboxylate reductase & amino acid synthesis \\
\hline Alga & Ttzw_012122 & 1.00 & $5.68 \mathrm{e}-05$ & amino acid transmembrane transporter & transport \\
\hline Alga & Ttzw_016083 & 1.00 & $3.74 \mathrm{e}-04$ & amino acid transporter & transport \\
\hline Alga & Ttzw_009365 & 1.00 & $2.74 \mathrm{e}-06$ & glutamine-hydrolyzing asparagine synthase & nitrogen metabolism \\
\hline Alga & Ttzw_018410 & 1.00 & $2.59 \mathrm{e}-05$ & amidase signature enzyme & nitrogen metabolism \\
\hline Alga & Ttzw_009232 & 1.00 & $2.66 \mathrm{e}-25$ & class I glutamine amidotransferase & nitrogen metabolism \\
\hline
\end{tabular}

The non-symbiotic fungus and alga were grown on a medium under a laboratory condition that was totally different from the condition in nature. The overrepresentation of GO terms related to metabolic processes and transmembrane transports implies that the down-regulated genes include considerable number of genes induced under such specific culture conditions. To accomplish our aim to identify genes involved in the symbiotic interaction we further focused on the consistent up-regulated genes as 'symbiosis-related genes'. 


\section{Establishment of the symbiotic interface}

Inside the thalli fungal hyphae attach to algal cells with structures called haustoria. In the case of fruticose ascomycetous lichens with trebouxioid photobionts, including Usnea species, fungal hyphae are observed to grow into but do not penetrate the algal cell walls [2, 53-55]. At a haustorium, a thick hydrophilic layer overlies the fungal cell wall the outer part of which is covered by a hydrophobic layer that spreads to the surface of algal cell walls $[2,56]$. The hydrophilic layer is known to absorb water at hydration and the hydrophobic layer to seal the apoplastic continuum of the fungus and the alga, together producing passive fluxes of water and nutritional solutes from the thallus exterior to the interior algal layer (Fig. 2a) [2, 56, 57]. The hydrophobic layer secures gas-filled zones inside the thallus even at full hydration which is a prerequisite for efficient $\mathrm{CO}_{2}$ diffusion to the algal cells. The symbiosis-related genes identified in this study include many genes that are likely to be involved in producing a functional symbiotic interface.

\section{Cell wall modification}

In $U$. hakonensis, the three fungal symbiosis-related glycoside hydrolase genes, Uhk_019559, Uhk_007999, and Uhk_005214, may function in the degradation of algal and fungal cell walls during the morphogenesis of haustoria (Fig. 2b). Uhk_019559 and Uhk_007999 possibly degrade cellulose and hemicellulose in algal cell walls [58-60] when fungal hyphae grow to reach algal cells and develop haustorial structures at the contact sites [2, 53]. Uhk_005214 may break down beta-1,3-glucan in fungal cell walls at haustoria where algal and fungal cell walls were reported to be thinner $[61,62]$, possibly causing local loosening of the fungal wall that could facilitate transport between the symbionts. Uhk_002614 may possibly be involved in the production of the hydrophilic layer comprises of polysaccharides (Fig. 2c) [63].

\section{Hydrophobic layer}

In lichens, hydrophobins have been identified in the region where hyphae are in contact with algal cells [26, 56, 57, 64-66] called the hydrophobic layer. A class I hydrophobin gene identified in Xanthoria parietina (XPH1) was indicated to be indispensable for the maintenance of a symbiotic relationship [65]. In the present study, Uhk_01658 showed significant up-regulated expression in both symbiotic states despite differences in the developmental stages and growth conditions of the two. Our

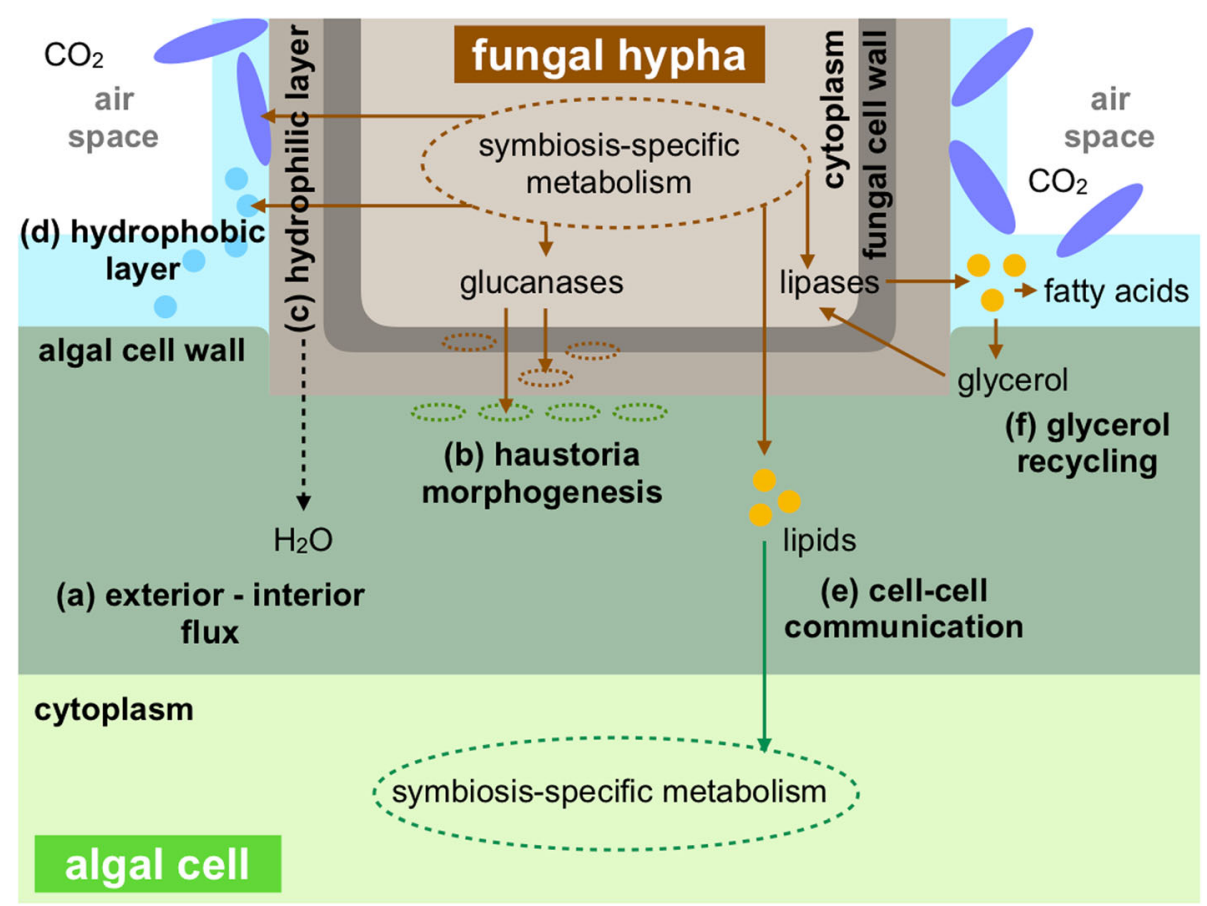

Fig. 2 Hypothesis of the symbiotic interface establishment in Usnea hakonensis. a The hydrophilic cell wall layer and the hydrophobic layer produce passive fluxes of water and nutritional solutes from the thallus exterior to interior algal cells, securing gas-filled space for efficient $\mathrm{CO}_{2}$ diffusion. b Fungal glycoside hydrolases degrade the fungal and algal cell walls, let a hyphal tip grow into the algal cell wall and form a haustorium. c The hydrophilic layer containing polysaccharides produced by fungal glycosyltransferases overlies the surface of the fungal cell wall. d The hydrophobic layer consisting of mycobiont-derived hydrophobins, secondary metabolites, lipids, and fatty acids, seals the surface of fungal and algal cell walls. e The lipid-derived communication tools are used by the mycobiont to communicate with the photobiont. $\mathbf{f}$ Fungal lipases degrade lipids and release glycerol that is recycled by the mycobiont 
results suggest that this hydrophobin could be the main component of the hydrophobic layer and may play an important role throughout the symbiotic interaction (Fig. 2d).

The majority of lichens are known to deposit secondary metabolites most of which are unique to lichens. Crystals of secondary metabolites are often observed within and on the hydrophobic layer and are thought to enhance the hydrophobicity of the layer [2]. A symbiosis-related gene encoding a polyketide synthase (Uhk_016999) showed high similarity only to a polyketide synthase identified in $U$. longissimi (GenBank accession: AEJ54468.1). The up-regulated expression of this gene in both symbiotic states suggests that this gene may be involved in the synthesis of symbiosis-specific metabolites specific to these two species or possibly to genus Usnea.

Lipids and fatty acids are also reported as components of the hydrophobic layer [28]. Expression of genes involved in sphingolipid and phospholipid biosynthesis was up-regulated in the symbiotic states (Uhk_003277, Uhk_017380, and Uhk_017885). Sphingolipids and phospholipids are constitutive lipids of membrane microdomains and extracellular vesicles respectively $[29,30,67$, 68], both reported to be involved in the communication between symbiotic partners [69-73]. The up-regulated expression of the genes involved in these fungal lipid metabolisms might suggest that lipids are not merely the components of the hydrophobic layer but also used as fungal tools to communicate with algal partners (Fig. 2e).

At least two fungal symbiosis-related genes are predicted to encode lipases (Uhk_003579 and Uhk_013145). Joneson et al. [12] reported up-regulated expression of Lip 3 in the second stage (contact) of lichenization in the lichen-forming fungus Cladonia grayi. Inferred from extracellular activity of Lip3, they suggested that lipids in the hydrophobic layer could be the targets of the secreted lipase. We likewise assume that the two lipases might hydrolyse fungal (or possibly algal) lipids (possibly triacylglycerols) in the layer, releasing fatty acids instead. Glycerol released with fatty acids by lipid digestion may be recycled in fungal cells as indicated by the symbiosisrelated expression of a glycerol transporter (Uhk_011461) and a glycerol dehydrogenase (Uhk_011759) (Fig. 2f).

\section{Nutrient flow between the fungal and algal partners}

The mutualistic symbiosis of lichens is ensured by benefit which both fungal and algal partners have from the relationship. The mycobiont receives carbohydrates produced by the photosynthesis of the photobiont, whereas the photobiont receives a suitable environment and nutrients for the photosynthesis. To initiate and maintain such a relationship, nutrients must be sufficiently produced and efficiently transferred between the symbiotic partners. In this study, genes involved in photosynthesis and transport of carbohydrate, phosphate, and nitrogen were identified as symbiosis-related genes. The resynthesized thalli we used to extract RNA were protrusions formed on top of fungal colonies where neither fungal nor algal cells have direct access to nutrients in the medium (Fig. 1). Therefore, the identified symbiosisrelated transporter genes are most likely involved in nutrient transport from the symbiotic interface rather than that from the medium.

\section{Carbon flow}

Production In the $U$. hakonensis system, the five carbon polyol ribitol, is produced by algal photosynthesis and transported to the mycobiont $[37-40,74] .$. The enhanced expression of photosynthesis genes in the symbiotic states implies modifications under the constraints of the symbiosis, that possibly guarantee adequate carbohydrate supply for the entire thallus (Fig. 3a). The upregulation of algal symbiosis-related gene Ttzw_014612, corresponding to the D1 reaction centre protein in photosystem II (PSII), could be a part of an adaptation to the symbiotic lifestyle that imposes higher light intensities on the photobiont than the non-symbiotic lifestyle [75]. The D1 reaction centre protein is known as the primary target of light-induced oxidative damage. The immediate replacement of damaged D1 proteins is vital for photosynthetic organisms to avoid inactivation of PSII [76]. In the green alga Chlamydomonas reinhardtii, expression of the D1 protein gene is mainly regulated at the level of translation while transcription has been reported to be constitutive [77]. If analogous regulation can be supposed, the up-regulated expression of the D1 protein gene in the symbiotic states indicates an increase in the number of stock transcripts in cells, thereby enabling rapid synthesis of D1 proteins, i.e., rapid recovery from photodamage.

The symbiosis-specific expression of carbonic anhydrase (CA) (Ttzw_000076) that may function in $\mathrm{CO}_{2}$ transport and fixation is likely to indicate algal adaptation to $\mathrm{CO}_{2}$ conditions inside a symbiotic structure. In symbiosis, the layered structure of a thallus could change $\mathrm{CO}_{2}$ concentration around algal cells. The change in $\mathrm{CO}_{2}$ conditions may induce expression of $\mathrm{CA}$ and increased enzyme concentration could ensure efficient transport and fixation of $\mathrm{CO}_{2}$. The expansion of a specific subclass of cytoplasmic $\beta$ CAs in the genome of Trebouxiaceae lichen-forming alga, Asterochloris glomer$a t a$, has been reported and a potential relationship to the lichen symbiosis was indicated [13]. Besides the important roles CAs play in photosynthesis, they may be involved in metabolic activities such as biosynthesis of amino acids, lipids, and development of nitrogen-fixing root nodules [33, 34]. The identification of symbiosis- 


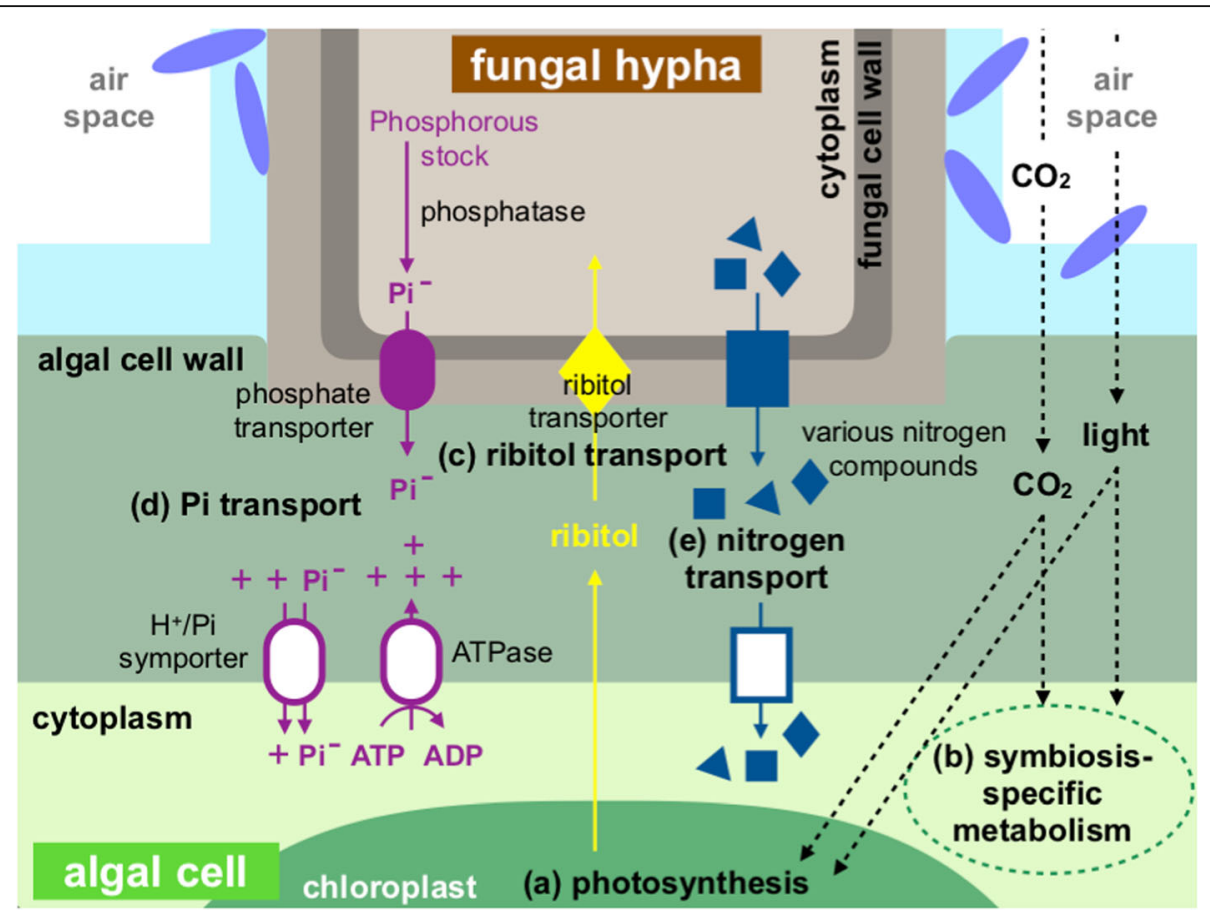

Fig. 3 Hypothesis of the symbiosis-specific nutrient transport between Usnea hakonensis and Trebouxia sp. a The photobiont adjusts photosynthetic activity to provide carbohydrates for the entire symbiotic structure. $\mathbf{b}$ Light and carbon dioxide conditions inside the symbiotic structure initiate symbiosis-specific metabolism of the photobiont. c Photosynthetic product, ribitol, is released to the symbiotic interface and imported by ribitol transporters of the mycobiont. $\mathbf{d}$ Phosphate is exported to the symbiotic interface by fungal phosphate transporters and taken up by algal phosphate transporters driven by the proton electrochemical gradient. e Various nitrogen compounds, such as amino acids, are transported from the mycobiont to the photobiont

related CAs in lichen-forming algae is intriguing because it raises the possibility of symbiotic-specific regulatory systems that may control algal metabolism via the $\mathrm{CO}_{2}$ condition inside a thallus.

Light-dependent regulation may also be involved in algal symbiosis-specific metabolism as indicated by the symbiosis-related ferredoxin:thioredoxin reductase (FTR) (Ttzw_014778). FTR is a key protein in the light-dependent regulation of carbon flow and various metabolic activities in photosynthetic organisms $[35,36]$. Richardson and Smith [40] reported that Trebouxia photobionts directly isolated from lichen thalli released ribitol from cells while cultured Trebouxia photobionts produced relatively more sucrose than ribitol and almost completely lost the ability to release fixed carbon. Such symbiosis-specific carbon metabolism could be regulated by the ferredoxin/thioredoxin system that links light to enzymatic activities. As light has been reported as an essential factor for the induction of a symbiotic phenotype [7], light condition in a thallus could probably be one of the triggers that initiate the regulatory system which induces algal metabolic activities required in the lichenization process (Fig. 3b).

Taken together, the functions of these algal symbiosisrelated genes may indicate not only enhanced photosynthetic activity of the photobiont but also adjustment of broader metabolic activities probably required to develop and stabilize the symbiotic lifestyle.

Transportation Ribitol excreted from photobiont cells to the symbiotic interface should be readily taken up by the mycobiont. Recently, Yoshino et al. found that transporters similar to the fungal ribitol transporter AmLAT2 [41] tend to be duplicated in most lichen-forming species in Lecanoromycetes [78]. They hypothesized that the duplication of ribitol transporter genes may be associated with lichenization events in Lecanoromycetes and is likely to enable the efficient utilization of ribitol. In line with their finding we identified three AmLAT2-like genes in the fungal transcriptome, two of which (Uhk_000003 and Uhk_000004) were up-regulated in the symbiotic states. Armaleo et al. [13] reported that one of the five putative ribitol transporters found in the C. grayi genome was induced in the early stage of lichenization. The up-regulated gene expression of the ribitol transporters in the early and late stages of lichenization may indicate their fundamental roles in lichenization (Fig. 3c).

\section{Phosphorus and nitrogen flow}

While carbohydrates are exclusively provided by the photobiont, other nutrients essential for various 
metabolic activities in lichens are provided by the mycobiont which has direct access to the surrounding environment. Nitrogen and phosphorus are known to affect the growth of lichens, and are suggested to be involved in the regulation of the symbiotic balance between the mycobiont and the photobiont [79-81].

The up-regulated expression of genes corresponding to fungal MFS phosphate transporter (Uhk_019687) and acid phosphatase (Uhk_006220), and algal transmembrane ATPase (Ttzw_021111) indicates that phosphorus is likely to be provided as inorganic phosphate $(\mathrm{Pi})$ from the mycobiont to the photobiont (Fig. 3d). In arbuscular mycorrhizal symbiosis, plant plasma membrane $\mathrm{H}^{+}$ATPase is proposed to create a proton electrochemical gradient across the membrane that energizes the uptake of Pi by Pi transporters [82, 83]. Algal Pi transporter genes were not identified as symbiosis-related but one algal $\mathrm{H}^{+}$/ Pi symporter gene was significantly up-regulated in the natural thalli (Table 6).

Unlike carbon and phosphorous, no symbiosis-related transporters were identified for nitrogen transport between the symbionts. (Fig. 3e and Table 7). Previous genetic studies on early stages of lichenization reported increased expression of fungal ammonium transporter genes $[11,13]$. However in the present study fungal ammonium transporter genes showed no up-regulated expression in either the resynthesized or the natural symbiotic state relative to the non-symbiotic state. The inconsistency between the two symbiotic states and the previous studies may simply reflect the difference in accessible nitrogen sources, or may possibly reflect stage-specific nitrogen metabolism. Further investigation is required to elucidate the mechanism of nitrogen transport in lichens. Nevertheless, symbiosis-specific nitrogen flow could be inferred from the symbiosis-related genes predicted to be involved in algal nitrogen metabolism ([Protein-PII] uridylyltransferase (Ttzw_019382) and glutamine amidotransferase (Ttzw_009103)). An interesting feature of $\mathrm{P}_{\text {II }}$ signaling proteins is that they can integrate a nitrogen signal with a carbon signal and thereby coordinate the cellular balance of nitrogen and carbon $[44,45]$. The indicated involvement of $\mathrm{P}_{\text {II }}$ proteins in algal symbiosis-specific nitrogen metabolism might enable the mycobiont to control the carbon metabolism of the photobiont via nitrogen supply, which would possibly help balance the growth of the symbionts.

\section{Conclusion}

From the predicted functions of the identified symbiosis-related genes, we hypothesize specific genetic involvement in two key events in the later stages of lichenization. 1) Establishment of the symbiotic interface, namely the modification of cell walls at fungal-algal contact sites and the production of hydrophobic layer
(Fig. 2). 2) Exchange of nutrients (carbon, phosphorous, and nitrogen) between the symbionts across the symbiotic interface (Fig. 3). The genetic indications presented here may provide important information to understand symbiosis-specific transport and metabolism. Several genes were found to be homologous to symbiosis-related genes previously reported by genetic studies on early stages of lichenization. The commonalities between early and later stages in different lichen-forming species may reflect the fundamental genetic adjustment characteristic of the lichen symbiosis. An interesting implication for future studies is that the light and carbon dioxide conditions inside a sheath of the hydrophobic layer or a thallus may induce algal metabolic activities that might be required in later lichenization stages. To evaluate the significance of the identified symbiosis-related genes in lichenization process, gene expression in earlier or later developmental stage than the one used in this study should also be examined. Our study has shown that the Usnea hakonensis system is an ideal model for the genetic study of lichenization and further investigation into this system will provide important information to elucidate the genetic basis of lichen symbiosis.

\section{Methods}

\section{Strains and culture condition}

Strains of Usnea hakonensis and Trebouxia sp. were isolated from a thallus collected from Kanagawa prefecture, Japan $\left(35^{\circ} 26^{\prime} \mathrm{N}, 139^{\circ} 10^{\prime} \mathrm{E}\right)$ in 2008 . The fungal and algal strains have been constantly re-plated in our laboratory on slant MY medium [containing $2 \%(\mathrm{w} / \mathrm{v})$ malt extract, $0.2 \%(\mathrm{w} / \mathrm{v})$ yeast extract, $\mathrm{pH} 5.8]$ and $\mathrm{C}$ medium [containing, $15 \mathrm{mg} \mathrm{Ca}\left(\mathrm{NO}_{3}\right)_{2} \cdot 4 \mathrm{H}_{2} \mathrm{O}, 10 \mathrm{mg} \mathrm{KNO}{ }_{3}, 5 \mathrm{mg} ß$ $\mathrm{Na}_{2}$ glycerophosphate $5 \mathrm{H}_{2} \mathrm{O}, 4 \mathrm{mg} \mathrm{MgSO}_{4} \cdot 7 \mathrm{H}_{2} \mathrm{O}, 0.01 \mu \mathrm{g}$ vitamin $\mathrm{B}_{12}, 0.01 \mu \mathrm{g}$ Biotin, $1 \mu \mathrm{g}$ Thiamine $\mathrm{HCL}, 0.3 \mathrm{~mL}$ PIV metals (100 mg Na 2 EDTA. $2 \mathrm{H}_{2} \mathrm{O}, 19.6 \mathrm{mg} \mathrm{FeCl} \cdot 6 \mathrm{H}_{2} \mathrm{O}$, $3.6 \mathrm{mg} \mathrm{MnCl}_{2} \cdot 4 \mathrm{H}_{2} \mathrm{O}, 1.04 \mathrm{mg} \mathrm{ZnCl}_{2}, 0.4 \mathrm{mg} \mathrm{CoCl} \cdot 6 \mathrm{H}_{2} \mathrm{O}$, $0.25 \mathrm{mg} \mathrm{Na} 2 \mathrm{MoO}_{4} \cdot 2 \mathrm{H}_{2} \mathrm{O}$, in $100 \mathrm{~mL}$ solution), $50 \mathrm{mg}$ Tris, per $100 \mathrm{~mL}$ of medium, pH 7.5] [84], respectively.

\section{Genome sequencing and de novo assembly of the fungus} Fungal genomic DNA was extracted from the culture of the fungal strain using a NucleoSpin Plant II kit (Macherey-Nagel, Düren, Germany) following the manufacturer's protocol for fungi. DNA libraries were constructed using a TruSeq Nano DNA Library Preparation Kit (Illumina, Inc., San Diego, CA) following the manufacturer's instructions. Short DNA sequences (paired-end 125 bp) were determined from the libraries using the Illumina HiSeq2500 platform. After the removal of adaptor sequences and low-quality reads, the reads were assembled into contigs by using CLC genomic workbench (https:// www.qiagenbioinformatics.com/) with a word size of 64 and the contigs were assembled into scaffolds using 
distance information provided by the read pairs. The completeness of the fungal and algal genome assembly was assessed by screening for 303 core eukaryotic genes with BUSCO v3.0.2 [85]. The basic features of the fungal and algal genomes were analysed by using QUAST v 4.5.4 [86] and AGAT v0.4.0 [87].

\section{Sample preparation for RNA sequencing}

For the comparative transcriptomic analysis, fungal and algal samples in non-symbiotic and two symbiotic states were used. For each sample type three biological replicates were prepared.

The non-symbiotic fungal and algal samples and the resynthesized symbiotic samples were prepared axenically. For the non-symbiotic samples, the fungal and algal strains were inoculated to new media as described in "Strains and culture condition" section. For the resynthesized symbiotic samples, the fungal and algal strains were co-cultured following the method described in Kon et al. (Usnea confuse ssp. kitamiensis used in the study was later reidentified as $U$. hakonensis) [17] with slight modification. First, actively growing fungal colonies were mildly homogenized with sterilized water using a mortar and a pestle. Then freshly sampled algal colonies, one third of the fungus in wet weight, were added and mixed. The mixture was inoculated onto slant MY media (the concentration was diluted to $1 / 4$ of the MY medium used for the fungal strain) by using a spatula. All sample types were cultured under a $12 \mathrm{~h} / 12 \mathrm{~h}$ lightdark cycle, approximately $20 \mu \mathrm{mol} \mathrm{m}{ }^{-2} \mathrm{~s}^{-1}$ illumination at $18{ }^{\circ} \mathrm{C}$. The non-symbiotic fungal and algal samples were collected 1 month after the inoculation. The resynthesized symbiotic samples, thallus-like fibrils which developed on top of fungus-alga mixed colonies, were collected with sterilized tweezers 3 months after the inoculation. The culture period and condition of the resynthesized symbiotic samples were decided in an attempt to gain comparable transcriptomes by means of growth and metabolic activities. Thallus-like fibrils usually start to grow 1-1.5 months after the start of co-culturing (inoculation) and subsequently reach the peak of growth in approximately 1-1.5 months. Therefore to have comparable growth between the non-symbiotic and resynthesized symbiotic samples, the non-symbiotic cultures were sampled 1 month after the inoculation while the resynthesized thalli were sampled 3 months after. Likewise, we used inorganic medium to grow the non-symbiotic algal cultures to limit the algal carbon source to the photosynthetic products as it is in the symbiotic samples.

The natural symbiotic samples, thalli of $U$. hakonensis, were collected in 2017 at the same location as 2008. The thalli were put into RNA-later in the field immediately after the sampling. The fungal internal transcribed spacer (ITS) rDNA sequence of the natural thalli was determined by the Sanger sequencing. The thalli which presented the identical ITS rDNA sequence to the fungal stain were used for the RNA sequencing. All samples were stored in RNA-later at $-80^{\circ} \mathrm{C}$ until RNA extraction.

RNA extraction, library construction, and sequencing The total RNA of all sample types were extracted using a RNeasy mini kit (QIAGEN, Venlo, the Netherlands) following the manufacturer's protocol for plants. RNA libraries for the cultured samples (non-symbiotic and resynthesized) were constructed using the NEBNext Poly(A) mRNA Magnetic Isolation Module and the NEBNext Ultra RNA Library Prep Kit for Illumina (New England Bio Labs, Ipswich, MA) following the manufacturer's instructions, whereas the NEBNext Ultra Directional RNA Library Prep Kit for Illumina was used for the natural symbiotic samples. Short cDNA sequences (paired-end $125 \mathrm{bp}$ ) were determined from the libraries using the Illumina Hiseq2500 platform.

\section{Genome annotation}

Scaffolds longer than $2 \mathrm{~kb}$ of the fungal genome assembled in this study and the algal genome assembled previously [21] (DDBJ accessions: BLJB01000001-BLJB01000879 and BDIU01000001-BDIU01000677, respectively) were annotated using the RNA-seq reads. First, reference annotations for each genome were constructed by using strand-specific reads of the natural thalli as follows. After combining the reads from the three replicates, the reads were mapped to the genome by TopHat v2.1.0 using a library type option for strand-specific libraries $[88,89]$, and genes were assembled by using Cufflinks v2.1.1 [90]. Then, the reads from the non-symbiotic cultures and the resynthesized thalli were mapped to the reference using an option for unstranded library type in order to complement the annotation for genes that are specifically expressed in the cultured samples. During the annotation, a few reads derived from mRNAs with read-through sequences at the 3 ' ends connected to adjacent genes and caused prediction of excessive overlapped or large fused genes. Therefore, reads mapped to genomic positions with coverage lower than a cut-off value were eliminated by using SAMtools v1.3.1 [91] and Bedtools v2.26.0 [92]. For each sample type (non-symbiotic, resynthesized symbiotic, and natural symbiotic), the cut-off values were decided as follows: 1) The reads of the three replicates were combined and mapped to the appropriate genome by TopHat v2.1.0; 2) Genes were first assembled without cut-off values by using Cufflinks v2.1.1 (The number of genes in this assembly was defined as 'initial gene number'); and 3) Several cut-off values were tested, and for each value, genes were tentatively assembled. Application of lower to higher cut-off values first increased the number of assembled genes attributable to the excision of fused genes. However, 
the number later decreased due to the exclusion of genes with lower expression. Considering the deleterious effect of fused genes in the downstream differential expression analysis, we prioritized the excision of fused genes. Among the tested cut-off values, we selected the value that gave the number of assembled genes equivalent to the 'initial gene number'.

\section{Differential expression analysis and identification of symbiosis-related genes}

The reads derived from each sample type were mapped to the annotated genomes by using CLC genomics workbench (https://www.qiagenbioinformatics.com). Expression value, RPKM (Reads Per Kilobase of exon model per Million mapped read) of each gene were calculated from the number of reads mapped to the gene [93]. The RPKM of the three replicates were compared between the symbiotic and non-symbiotic sample types by using the Empirical analysis of the DGE tool incorporated in the CLC genomics workbench using default parameters. The Empirical analysis of the DGE implements the 'Exact Test', which accounts for overdispersion caused by biological and technical variability, to assess differential expression between two experimental groups each consist of several replicates. The tool was developed by Robinson and Smyth [94] and incorporated in the EdgeR Bioconductor packages [95]. Bonferroni correction was applied to the $p$-values calculated by the tool and differentially expressed genes (DEGs) with corrected $p$-value $<0.05$ were considered significant. The fungal and algal significant DEGs were first detected in independent comparisons of the resynthesized and natural thalli with the non-symbiotic cultures. Then the significant up-regulated genes that were common in the two symbiotic states were defined as 'symbiosis-related genes' (see Discussion). The mRNA sequences of the fungal and algal symbiosis-related genes were subjected to BLASTX searches against the NCBI non-redundant protein database (nr) with an $e$-value cut-off of $1 \mathrm{e}$ - 40 . Based on the predicted functions from the BLASTX and literature searches the genes were manually categorized following the biological process categories of Gene Ontology (GO).

Over-represented GO terms among the significant DEGs from each comparison were identified using the R-based topGO (v2.40.0) package [96] (https://www.r-project.org). Protein-coding sequences within the fungal and algal mRNA sequences were predicted by using TransDecoder (v5.5.0 https://transdecoder.github.io) [97]. InterProScan (v5.30-69.0) [98] was used to annotate GO terms to each predicted protein sequence. The topGO weight01 algorithm was applied with Fisher's Exact Test to the significant up-/down-regulated genes consistent between the resynthesized and natural symbiotic states. GO terms annotated to at least 10 genes and with $p$-values of $<0.01$ were considered significantly over-represented.

\section{Searches for candidates of symbiosis-related genes in the fungal transcriptome}

Besides the differential expression analysis, genes encoding hydrophobins and ribitol transporters were searched by tBLASTX in the transcriptome of $U$. hakonensis. As queries, fungal sequences predicted as hydrophobins and ribitol transporters were obtained from the NCBI database. In searches for ribitol transporters, two L-arabinose transporters were chosen from Ambrosiozyma manospora: AmLAT1 (AY923868.1) and AmLAT2 (AY923869.1), substrates: L-arabinose, L-arabitol, ribitol. Three polyol transporters were chosen from Debaryomyces hansenii: DhStl1 (CAG87598.2), substrate: glycerol, DhSyl1 (CAR65543.1), substrates: D-sorbitol, D-mannitol, ribitol, D-arabitol, Dgalactitol), and DhSyl2 (CAG86001.1), substrates: D-sorbitol, D-mannitol, ribitol, D-arabitol) [78].

\section{Supplementary information}

Supplementary information accompanies this paper at https://doi.org/10. 1186/s12864-020-07086-9.

Additional file 1: Table S1. The results of RNA-seq. Table S2 GO terms enriched ( $p$-value $<0.01$ ) among the fungal genes signifcantly upregulated in the symbiotic states. Table S3 GO terms enriched ( $p$-value < $0.01)$ among the fungal genes signifcantly down-regulated in the symbiotic states. Table S4 GO terms enriched ( $p$-value $<0.01$ ) among the algal genes signifcantly up-regulated in the symbiotic states. Table S5 GO terms enriched ( $p$-value $<0.01$ ) among the algal genes signifcantly down-regulated in the symbiotic states.

\section{Abbreviations \\ CA: Carbonic anhydrase; DEG: Differentially expressed gene; \\ FTR: Ferredoxin:thioredoxin reductase; GO: Gene ontology; ITS: Internal transcribed spacer; Pi: Inorganic phosphate; PSII: Photosystem II; RPKM: Reads Per Kilobase of exon model per Million mapped read}

\section{Acknowledgements}

Not applicable.

\section{Authors' contributions}

MK: planning of research, fungal and algal culturing, all molecular experiments, genomic and transcriptomic analysis, and manuscript writing; YK: planning of research, field collection of Usnea hakonensis, fungal and algal isolation and culturing, resynthesis experiment, and helpful discussion on manuscript writing; YO: planning of research, field collection and species identification of Usnea hakonensis, and helpful discussion on manuscript writing; YS: planning of research and helpful discussion on manuscript writing; YT: planning of research, all molecular experiments, genomic and transcriptomic analysis, and manuscript writing; All authors read and approved the final manuscript.

Funding

An internal SOKENDAI grant to Y. T.

\section{Availability of data and materials}

The fungal and algal annotated genomes were deposited in DDBJ under the accession numbers BLJB01000001-BLJB01000879 and BDIU01000001-

BDIU01000677, respectively. All the data used in this study was archived in DDBJ Sequence Read Archive under the accession number DRA009335. The nucleotide sequences of AmLAT1 (AY923868.1), AmLAT2 (AY923869.1), DhStl1 
(CAG87598.2), DhSyl1 (CAR65543.1), and DhSyl2 (CAG86001.1) were obtained from the NCBI database.

\section{Ethics approval and consent to participate}

No permission was required to collect the species used in this study.

\section{Consent for publication}

Not applicable.

\section{Competing interests}

The authors declare that they have no competing interests.

\section{Author details}

${ }^{1}$ SOKENDAI (The Graduate University for Advanced Studies), Department of Evolutionary Studies of Biosystems, Shonan Village, Hayama, Kanagawa 240-0193, Japan. Department of Botany, Swedish Museum of Natural History, P.O. Box 50007, SE-104 05 Stockholm, Sweden. ${ }^{3}$ Tokyo Metropolitan Hitotsubashi High School, 1-12-13 Higashikanda, Chiyoda-ku, Tokyo 101-0031, Japan. ${ }^{4}$ Department of Botany, National Museum of Nature and Science, 4-1-1 Amakubo, Tsukuba, Ibaraki 305-0005, Japan.

\section{Received: 30 April 2020 Accepted: 21 September 2020}

\section{Published online: 29 September 2020}

\section{References}

1. Nash TH. Lichen biology. 2nd ed. United States of America: Cambridge University Press, New York; 2008.

2. Honegger R. The symbiotic phenotype of lichen-forming Ascomycetes and their Endo- and Epibionts. In: Hock B, editor. Fungal associations. The Mycota (A Comprehensive Treatise on Fungi as Experimental Systems for Basic and Applied Research). 2nd ed. Berlin, Heidelberg: Springer; 2012. p. 287-339.

3. Ahmadjian V. The lichen Symbiosis. New York: Wiley; 1993.

4. Aschenbrenner IA, Cernava T, Berg G, Grube M. Understanding microbial multi-species symbioses. Front Microbiol. 2016;7(180):180.

5. Spribille T, Tuovinen V, Resl P, Vanderpool D, Wolinski H, Aime MC, et al. Basidiomycete yeasts in the cortex of ascomycete macrolichens. Science 2016;353(6298):488-92.

6. Tuovinen V, Ekman S, Thor G, Vanderpool D, Spribille T, Johannesson H. Two basidiomycete fungi in the cortex of wolf lichens. Curr Biol. 2019;29(3): 476-83. e5.

7. Biont AV, Interactions I. Development of synthetic and natural lichens. The Lichen Symbiosis. New York: Wiley; 1993. p. 53-98.

8. Galun M. CRC handbook of lichenology. Boca Raton: CRC Press; 1988.

9. Joneson S, Lutzoni F. Compatibility and thigmotropism in the lichen symbiosis: a reappraisal. Symbiosis. 2009;47(2):109-15.

10. Trembley ML, Ringli C, Honegger R. Morphological and molecular analysis of early stages in the resynthesis of the lichen Baeomyces rufus. Mycol Res. 2002;106(7):768-76.

11. Wang Y-Y, Liu B, Zhang X-Y, Zhou Q-M, Zhang T, Li H, et al. Genome characteristics reveal the impact of lichenization on lichen-forming fungus Endocarpon pusillum Hedwig (Verrucariales, Ascomycota). BMC Genomics. 2014;15(1):34

12. Joneson S, Armaleo D, Lutzoni F. Fungal and algal gene expression in early developmental stages of lichen-symbiosis. Mycologia. 2011;103(2):291-306.

13. Armaleo D, Müller $O$, Lutzoni F, Andrésson ÓS, Blanc $G$, Bode HB, et al. The lichen symbiosis re-viewed through the genomes of Cladonia grayi and its algal partner Asterochloris glomerata. BMC Genomics. 2019;20(1):605.

14. Schaper T, Ott S. Photobiont selectivity and interspecific interactions in lichen communities. I. Culture experiments with the mycobiont Fulgensia bracteata. Plant Biol. 2003:5(4):441-50.

15. Meeßen J, Ott S. Recognition mechanisms during the pre-contact state of lichens: I. Mycobiont-photobiont interactions of the mycobiont of Fulgensia bracteata. Symbiosis. 2013:59(3):121-30.

16. Honegger R. Morphogenesis. In: Nash III TH, editor. Lichen biology. 2nd ed. New York: Cambridge University Press; 2008. p. 69-93.

17. Kon Y, Kashiwadani H, Masada M, Tamura G. Artificial syntheses of mycobionts of Usnea confusa ssp. kitamiensis and Usnea orientalis with their natural and nonnatural phycobiont. J Jpn Bot. 1993;68:129-37.

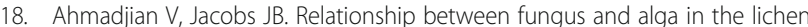
Cladonia cristatella Tuck. Nature. 1981;289(5794):169.
19. Ohmura Y. Taxonomic study of the genus Usnea (lichenized Ascomycetes) in Japan and Taiwan. J Hattori Bot Lab. 2001:90:1-96.

20. Kon Y, Kashiwadani H, Kurokawa S. Induction of lichen thalli of Usnea confusa Asah. Ssp. kitamiensis Asah.) Asah. In vitro. J Jpn Bot 1990;65:26-32.

21. Kono M, Tanabe H, Ohmura Y, Satta Y, Terai Y. Physical contact and carbon transfer between a lichen-forming Trebouxia alga and a novel Alphaproteobacterium. Microbiology. 2017;163:678-91.

22. Domozych DS, Ciancia M, Fangel JU, Mikkelsen MD, Ulvskov P, Willats WGT. The cell walls of green algae: a journey through evolution and diversity. Front Plant Sci. 2012;3:82

23. Bowman SM, Free SJ. The structure and synthesis of the fungal cell wall. Bioessays. 2006;28(8):799-808.

24. Gow NA, Latge J-P, Munro CA. The fungal cell wall: structure, biosynthesis, and function. Microbiol Spectr. 2017;5(3):1-25

25. Beauvais A, Latgé J-P. Special Issue: Fungal Cell Wall. J Fungi. 2018;4(3):91

26. Scherrer S, De Vries OM, Dudler R, Wessels JG, Honegger R. Interfacial self-assembly of fungal hydrophobins of the lichen-forming ascomycetes Xanthoria parietina and X. ectaneoides. Fungal Genet Biol. 2000:30(1):81-93.

27. Elix J, Stocker-Wörgötter E. Biochemistry and secondary metabolites. In: Nash III TH, editor. Lichen biology. 2nd ed. New York: Cambridge University Press; 2008. p. 104-33.

28. Honegger R. Ultrastructural studies in lichens: II. Mycobiont and Photobiont Cell-Wall surface-layers and adhering crystalline lichen products in four Parmeliaceae. New Phytol. 1986;103:0-797.

29. Fernandes CM, Goldman GH, Del Poeta M. Biological roles played by sphingolipids in dimorphic and filamentous fungi. mBio. 2018;9(3): e00642-18

30. Cassilly C, Reynolds T. PS, It's complicated: the roles of phosphatidylserine and phosphatidylethanolamine in the pathogenesis of Candida albicans and other microbial pathogens. J Fungi. 2018;4(1):28.

31. Consortium TU. UniProt: a worldwide hub of protein knowledge. Nucleic Acids Res. 2018;47(D1):D506-D15

32. Kanehisa M, Goto S. KEGG: Kyoto encyclopedia of genes and genomes. Nucleic Acids Res. 2000;28(1):27-30

33. DiMario RJ, Clayton H, Mukherjee A, Ludwig M, Moroney JV. Plant carbonic anhydrases: structures, locations, evolution, and physiological roles. Mol Plant. 2017:10(1):30-46.

34. Aspatwar A, Haapanen S, Parkkila S. An update on the metabolic roles of carbonic anhydrases in the model alga Chlamydomonas reinhardtii. Metabolites. 2018;8(1):22.

35. Couturier J, Touraine B, Briat J-F, Gaymard F, Rouhier N. The iron-sulfur cluster assembly machineries in plants: current knowledge and open questions. Front Plant Sci. 2013;4:259.

36. Schürmann P, Buchanan BB. The ferredoxin/thioredoxin system of oxygenic photosynthesis. Antioxid Redox Signal. 2008;10(7):1235-74.

37. Lines CEM, Ratcliffe RG, Rees TAV, Southon TE. A 13C NMR study of photosynthate transport and metabolism in the lichen Xanthoria calcicola Oxner. New Phytol. 1989:111(3):447-56.

38. Hill DJ, Smith DC. Lichen physiology XII. The 'inhibition technique'. New Phytol. 1972:71(1):15-30

39. Richardson DHS, Hill DJ, Smith DC. Lichen physiology: xi. The role of the alga in determining the pattern of carbohydrate movement between lichen Symbionts. New Phytol. 1968;67(3):469-86.

40. Richardson DHS, Smith DC. Lichen physiology. X. The isolated algal and fungal symbionts of Xanthoria aureola. New Phytologist. 1968;67(1):69-77.

41. Londesborough J, Richard P, Valkonen M, Viljanen K. Effect of C-terminal protein tags on pentitol and l-arabinose transport by Ambrosiozyma monospora Lat1 and Lat2 transporters in Saccharomyces cerevisiae. Appl Environ Microbiol. 2014:80(9):2737-45.

42. Pereira I, Madeira A, Prista C, Loureiro-Dias MC, Leandro MJ. Characterization of new polyol/H+ symporters in Debaryomyces hansenii. PLoS One. 2014; 9(2):e88180.

43. Proudfoot M, Kuznetsova E, Brown G, Rao NN, Kitagawa M, Mori H, et al. General enzymatic screens identify three new nucleotidases in Escherichia coli biochemical characterization of SurE, YfbR, and YjjG. J Biol Chem. 2004; 279(52):54687-94

44. Forchhammer K, Lüddecke J. Sensory properties of the PII signalling protein family. FEBS J. 2016;283(3):425-37.

45. Huergo LF, Chandra G, Merrick M. PII signal transduction proteins: nitrogen regulation and beyond. FEMS Microbiol Rev. 2013;37(2):251-83. 
46. Liu H, Stephens TG, González-Pech RA, Beltran VH, Lapeyre B, Bongaerts P, et al. Symbiodinium genomes reveal adaptive evolution of functions related to coral-dinoflagellate symbiosis. Commun Biol. 2018;1(1):95.

47. Shinzato C, Shoguchi E, Kawashima T, Hamada M, Hisata K, Tanaka M, et al. Using the Acropora digitifera genome to understand coral responses to environmental change. Nature. 2011;476(7360):320.

48. Voolstra CR, Li Y, Liew YJ, Baumgarten S, Zoccola D, Flot J-F, et al. Comparative analysis of the genomes of Stylophora pistillata and Acropora digitifera provides evidence for extensive differences between species of corals. Sci Rep. 2017;7(1):17583

49. Moran NA. Symbiosis as an adaptive process and source of phenotypic complexity. Proc Natl Acad Sci. 2007;104(suppl 1):8627-33.

50. Shigenobu S, Watanabe H, Hattori M, Sakaki Y, Ishikawa H. Genome sequence of the endocellular bacterial symbiont of aphids Buchnera sp. APS Nat. 2000;407(6800):81-6.

51. Bonfante $P$, Genre A. Mechanisms underlying beneficial plant-fungus interactions in mycorrhizal symbiosis. Nat Commun. 2010;1:48.

52. Beckett R, Kranner I, Minibayeva FV. Stress physiology and the symbiosis. In: Nash III TH, editor. Lichen biology. New York: Cambridge University Press; 2008. p. 134-51.

53. Honegger R. Ultrastructural studies in lichens: I. Haustorial types and their frequencies in a range of lichens with trebouxioid photobionts. New Phytol. 1986;103(4):785-95.

54. Chervin RE, Baker GE, Hohl HR. The ultrastructure of phycobiont and mycobiont in two species of Usnea. Can J Bot. 1968;46(3):241-5.

55. Malachowski JA, Baker KK, Hooper GR. Anatomy and algal-fungal interactions in the lichen Usnea cavernosa. J Phycol. 1980;16(3):346-54

56. Honegger R. Functional aspects of the lichen symbiosis. Annu Rev Plant Biol. 1991;42(1):553-78.

57. Dyer PS. Hydrophobins in the lichen symbiosis. New Phytol. 2002;154(1):1-4.

58. Nascimento AS, Muniz JRC, Aparício R, Golubev AM, Polikarpov I. Insights into the structure and function of fungal $\beta$-mannosidases from glycoside hydrolase family 2 based on multiple crystal structures of the Trichoderma harzianum enzyme. FEBS J. 2014;281(18):4165-78.

59. Lombard V, Golaconda Ramulu H, Drula E, Coutinho PM, Henrissat B. The carbohydrate-active enzymes database (CAZy) in 2013. Nucleic Acids Res. 2013;42(D1):D490-D5.

60. Ahmadjian V. The Photobiont (Photosynthetic Symbiont). The Lichen Symbiosis. New York: Wiley; 1993. p. 30-52.

61. Chapman RL. Ultrastructural investigation on the foliicolous pyrenocarpous lichen Strigula elegans (Fée) Müll. Arg Phycol. 1976;15(2):191-6.

62. Meier JL, Chapman RL. Ultrastructure of the lichen Coenogonium interplexum Nyl. Am J Bot. 1983;70(3):400-7.

63. Honegger R, Haisch A. Immunocytochemical location of the $(1 \rightarrow 3)(1 \rightarrow 4)$ $\beta$-glucan lichenin in the lichen-forming ascomycete Cetraria islandica (Icelandic moss). New Phytol. 2001;150(3):739-46.

64. Trembley ML, Ringli C, Honegger R. Hydrophobins DGH1, DGH2, and DGH3 in the lichen-forming basidiomycete Dictyonema glabratum. Fungal Genet Biol. 2002;35(3):247-59.

65. Scherrer S, Haisch A, Honegger R. Characterization and expression of XPH1 the hydrophobin gene of the lichen-forming ascomycete Xanthoria parietina. New Phytol. 2002;154(1):175-84.

66. Trembley ML, Ringli C, Honegger R. Differential expression of hydrophobins $D G H 1, D G H 2$ and DGH3 and immunolocalization of DGH1 in strata of the lichenized basidiocarp of Dictyonema glabratum. New Phytol. 2002;154(1): 185-95

67. Farnoud AM, Toledo AM, Konopka JB, Del Poeta M, London E. Raft-like membrane domains in pathogenic microorganisms. Curr Topics Membr. 2015;75:233-68.

68. Guimarães LL, Toledo MS, Ferreira FA, Straus AH, Takahashi HK. Structura diversity and biological significance of glycosphingolipids in pathogenic and opportunistic fungi. Front Cell Infect Microbiol. 2014;4:138.

69. Bapaume L, Reinhardt D. How membranes shape plant symbioses: signaling and transport in nodulation and arbuscular mycorrhiza. Front Plant Sci. 2012;3:223.

70. Lefebvre FA, Lécuyer E. Small luggage for a long journey: transfer of vesicle-enclosed small RNA in interspecies communication. Front Microbiol. 2017;8:377.

71. Roth R, Hillmer S, Funaya C, Chiapello M, Schumacher K, Presti LL, et al. Arbuscular cell invasion coincides with extracellular vesicles and membrane tubules. Nat Plants. 2019;5(2):204.
72. Brown L, Wolf JM, Prados-Rosales R, Casadevall A. Through the wall: extracellular vesicles in gram-positive bacteria, mycobacteria and fungi. Nat Rev Microbiol. 2015;13(10):620.

73. de Toledo MS, Szwarc P, Goldenberg S, Alves LR. Extracellular Vesicles in Fungi: Composition and Functions; 2018.

74. Richardson DHS, Smith DC. Lichen physiology. IX. Carbohydrate movement from the Trebouxia Symbiont of Xanthoria aureola to the fungus. New Phytol. 1968;67(1):61-8.

75. Kranner I, Cram WJ, Zorn M, Wornik S, Yoshimura I, Stabentheiner E, et al. Antioxidants and photoprotection in a lichen as compared with its isolated symbiotic partners. Proc Natl Acad Sci U S A. 2005;102(8):3141-6.

76. Murata N, Takahashi S, Nishiyama Y, Allakhverdiev SI. Photoinhibition of photosystem II under environmental stress. Biochim Biophys Acta Bioenerg. 2007;1767(6):414-21.

77. Mulo P, Sakurai I, Aro EM. Strategies for psbA gene expression in cyanobacteria, green algae and higher plants: from transcription to PSII repair. Biochim Biophys Acta Bioenerg. 1817;2012:247-57.

78. Yoshino K, Yamamoto K, Hara K, Sonoda M, Yamamoto Y, Sakamoto K. The conservation of polyol transporter proteins and their involvement in lichenized Ascomycota. Fungal Biol. 2019;123(4):318-29.

79. Johansson O, Olofsson J, Giesler R, Palmqvist K. Lichen responses to nitrogen and phosphorus additions can be explained by the different symbiont responses. New Phytol. 2011;191(3):795-805

80. Palmqvist K, Franklin O, Näsholm T. Symbiosis constraints: strong mycobiont control limits nutrient response in lichens. Ecol Evol. 2017;7(18):7420-33.

81. Makkonen S, Hurri RS, Hyvärinen M. Differential responses of lichen symbionts to enhanced nitrogen and phosphorus availability: an experiment with Cladina stellaris. Ann Bot. 2007;99(5):877-84.

82. Wang W, Shi J, Xie Q, Jiang Y, Yu N, Wang E. Nutrient exchange and regulation in arbuscular mycorrhizal symbiosis. Mol Plant. 2017;10(9): 1147-58.

83. Karandashov V, Bucher M. Symbiotic phosphate transport in arbuscular mycorrhizas. Trends Plant Sci. 2005;10(1):22-9.

84. Ichimura T. Editor sexual cell division and conjugation-papilla formation in sexual reproduction of Closterium strigosum. International symposium on seaweed research, 7th, Sapporo; 1971. Tokyo: University of Tokyo Press; 1971.

85. Seppey M, Manni M, Zdobnov EM. BUSCO: assessing genome assembly and annotation completeness. Gene Prediction. 1962;2019:227-45.

86. Gurevich A, Saveliev V, Vyahhi N, Tesler G. QUAST: quality assessment tool for genome assemblies. Bioinformatics. 2013;29(8):1072-5.

87. Dainat J. AGAT: Another Gff Analysis Toolkit to handle annotations in any GTF/GFF format. (Version v0.4.0). Zenodo. doi: https://doi.org/10.5281/ zenodo.3552717. 2020.

88. Kim D, Pertea G, Trapnell C, Pimentel H, Kelley R, Salzberg SL. TopHat2: accurate alignment of transcriptomes in the presence of insertions, deletions and gene fusions. Genome Biol. 2013;14:R36.

89. Trapnell C, Pachter L, Salzberg SL. TopHat: discovering splice junctions with RNA-Seq. Bioinformatics. 2009;25:1105-11.

90. Trapnell C, Williams BA, Pertea G, Mortazavi A, Kwan G, Van Baren MJ, et al. Transcript assembly and quantification by RNA-Seq reveals unannotated transcripts and isoform switching during cell differentiation. Nat Biotechnol. 2010;28(5):511-5.

91. Li H, Handsaker B, Wysoker A, Fennell T, Ruan J, Homer N, et al. The sequence alignment/map format and SAMtools. Bioinformatics. 2009;25(16):2078-9.

92. Quinlan AR, Hall IM. BEDTools: a flexible suite of utilities for comparing genomic features. Bioinformatics. 2010;26(6):841-2.

93. Mortazavi A, Williams BA, McCue K, Schaeffer L, Wold B. Mapping and quantifying mammalian transcriptomes by RNA-Seq. Nat Methods. 2008;5(7): $621-8$.

94. Robinson MD, Smyth GK. Small-sample estimation of negative binomial dispersion, with applications to SAGE data. Biostatistics. 2008;9:321-32.

95. Robinson MD, McCarthy DJ, Smyth GK. edgeR: a bioconductor package for differential expression analysis of digital gene expression data. Bioinformatics. 2010;26(1):139-40.

96. Alexa A, Rahnenfuhrer Jö. topGO: Enrichment Analysis for Gene Ontology. R package version 2.40.0. 2020

97. Haas BJ, Papanicolaou A, Yassour M, Grabherr M, Blood PD, Bowden J, et al. De novo transcript sequence reconstruction from RNA-seq using the trinity platform for reference generation and analysis. Nat Protoc. 2013;8(8):1494-512. 
98. Jones P, Binns D, Chang H-Y, Fraser M, Li W, McAnulla C, et al. InterProScan 5: genome-scale protein function classification. Bioinformatics. 2014;30(9):1236-40.

\section{Publisher's Note}

Springer Nature remains neutral with regard to jurisdictional claims in published maps and institutional affiliations.

Ready to submit your research? Choose BMC and benefit from:

- fast, convenient online submission

- thorough peer review by experienced researchers in your field

- rapid publication on acceptance

- support for research data, including large and complex data types

- gold Open Access which fosters wider collaboration and increased citations

- maximum visibility for your research: over $100 \mathrm{M}$ website views per year

At BMC, research is always in progress. 